\title{
Postawy i zachowania młodych naukowców - doniesienie z pierwszego etapu badań międzynarodowych, ze szczególnym uwzględnieniem polskich respondentów
}

\author{
Marzena Świgoń \\ David Nicholas \\ CIBER Research Ltd.
}

Uniwersytet Warmińsko-Mazurski w Olsztynie

\begin{abstract}
Abstrakt
Cel/Teza: W artykule omówiono wybrane wyniki międzynarodowego projektu badawczego „Harbingers", których celem jest prognoza zmian w komunikacji naukowej na podstawie analizy postaw i zachowań współczesnych młodych pracowników naukowych. Uwagę skupiono w szczególności na wynikach uzyskanych w badaniach przeprowadzonych na grupie polskich respondentów, porównując je z wynikami uzyskanymi dla całej międzynarodowej grupy badawczej.

Koncepcja/Metody badań: Projekt „Harbingers” obejmuje badania prowadzone w siedmiu krajach w latach 2016-2018 metodą pogłębionych wywiadów indywidualnych z wykorzystaniem znormalizowanego kwestionariusza. Dodatkowo na zgromadzonych danych szczegółowych prowadzone są analizy statystyczne. W pierwszym etapie badań udział wzięło 116 młodych naukowców, w tym 10 z Uniwersytetu Warmińsko-Mazurskiego w Olsztynie.

Wyniki i wnioski: Większość respondentów z badanych krajów zwracała uwagę na przeciążenie obowiązkami zawodowymi, wysokie wymagania oraz niepewne warunki pracy. Widoczne było ich skupienie na finalnej części pracy naukowej, a mianowicie publikowaniu jak największej liczby artykułów w najbardziej prestiżowych czasopismach. Nie stwierdzono znaczących różnic w zachowaniach i postawach związanych z komunikacją naukową uczestniczących $\mathrm{w}$ badaniach polskich młodych naukowców, w stosunku do zachowań i postaw młodych badaczy z innych krajów.

Oryginalność/Wartość poznawcza: Prowadzone badania są pierwszymi na świecie długookresowymi studiami związanymi ze zmianami w systemie komunikacji naukowej wśród młodych pracowników nauki.
\end{abstract}

\section{Słowa kluczowe}

Badania międzynarodowe. Komunikacja naukowa. Młodzi naukowcy.

Otrzymany: 20 maja 2017. Zrecenzowany: 30 czerwca 2017. Poprawiony: 9 października 2017. Zaakceptowany: 28 grudnia 2017

\section{Wprowadzenie}

Młodzi pracownicy nauki są przedmiotem szczególnego zainteresowania w kontekście badań nad przyszłością komunikacji naukowej. Doktoranci i doktorzy przed 35. rokiem życia (ang. early career researchers) są bowiem nie tylko nową, ale też najliczniejszą grupą badaczy na świecie. Komunikacja naukowa zmienia się dynamicznie, głównie za sprawą 
rozwoju nowych technologii, m.in. mediów społecznościowych, społeczności wirtualnych i ruchu otwartej nauki. Interesujące i ważne wydają się obserwacje postaw i zachowań przedstawicieli tej generacji naukowców także z uwagi na fakt, że pracują oni w prekariackim środowisku, w warunkach niestałego zatrudnienia, czasowych kontraktów i niepewnej przyszłości (np. po skończeniu studiów doktoranckich).

Niniejszy artykuł dotyczy badań nad komunikacją naukową wśród młodych naukowców, prowadzonych w ramach międzynarodowego projektu Early Career Researchers - the harbingers of change? Celem tego projektu jest prognoza zmian, jakich można spodziewać się w komunikacji naukowej, na przykład w odniesieniu do Otwartej Nauki czy Nauki 2.0, która to idea jest wynikiem wpływu rozwoju technologii informacyjnych na globalny system komunikacji naukowej i edukacji (Nicholas et al., 2015b).

Na potrzeby projektu przyjęto umowną definicję młodych naukowców (wspomniani na wstępie doktoranci i doktorzy przed 35. rokiem życia), którą sformułowano na podstawie analizy innych określeń early-career researcher i jego rozumienia w światowej literaturze przedmiotu. Istnieją bowiem różne kryteria wyodrębniania „młodych pracowników nauki”, należą do nich m.in. czas pracy naukowej (pierwsze pięć lat pracy naukowej, do 10 lat po doktoracie, zob. Bazeley, 2003; Bridle et al., 2013) lub wiek (doktor do 35 lat, zob. Müller, 2014). W przyjętej definicji połączono te dwa najczęściej występujące kryteria.

W literaturze przedmiotu dotyczącej komunikacji naukowej wśród młodych naukowców podkreśla się, że są to bardzo kreatywni i pełni energii badacze, mogący odegrać kluczową rolę w ekonomii wiedzy na całym świecie (Friesenhahn \& Beaudry, 2014), którzy, niestety, pracują w szczególnie trudnych, prekariackich, niesprzyjających warunkach (Corkery et al., 2013; Graham et al., 2014; Müller, 2014a, 2014b; Fransman, 2014; James et al., 2009; Waaijer, 2016). Droga do niezależności naukowej, bardzo różnie rozumiana w różnych krajach (może nią być habilitacja, jak w Polsce albo stały etat na uczelni, tzw. tenure, jak w Stanach Zjednoczonych), jest dzisiaj dla młodych naukowców na całym świecie bardzo niepewna. Zatrudniani są na umowy czasowe, co stało się swoistą cechą współczesnego systemu edukacji wyższej w wielu krajach (Teichler \& Cummings, 2015). Niewielkie wynagrodzenia sprawiają, że zmuszeni są do podejmowania dodatkowego zatrudnienia, są przeciążeni i przepracowani (Bennion \& Locke, 2010; Brechelmacher et al., 2015).

Dotychczasowe analizy postaw i zachowań młodych badaczy w komunikacji naukowej dowodzą, że stanowią oni raczej konserwatywną grupę. Jest to ściśle związane ze stawianymi im wymaganiami, a szerzej z całym formalnym systemem oceny, promocji i awansów w środowisku naukowym. Przede wszystkim odczuwają znacznie większą presję publikowania w prestiżowych czasopismach niż czuli ją starsi naukowcy w przeszłości (a także dzisiaj), co sprawia, że żyją pod presją czasu i w stanie permanentnego niepokoju (Müller, 2014b; Friesenhahn \& Beaudry, 2014). W licznych badaniach dowiedziono, że współcześni młodzi naukowcy są niezmiernie skoncentrowani na liczbie publikowanych artykułów w czasopismach prestiżowych, w tym posiadających Impact Factor, oraz na liczbie cytowań, jaką osiągają ich teksty, ponieważ od tych czynników zależy zatrudnienie i dalsze etapy kariery (Harley et al., 2010; Housewright et al., 2013; Mulligan and Mabe, 2011; Van Dalen and Henkens, 2012; Waaijer, 2016). Wydaje się więc, że przed osiągnięciem niezależności naukowej raczej nie odważą się na jakieś rewolucyjne idee w zakresie przekształcania form komunikacji naukowej (Fransman, 2014; James et al., 2009; Housewright et al., 2013; Nicholas et al., 2015a; Watkinson et al., 2016). 
Zważywszy jednak na możliwości, jakie w komunikacji naukowej wiążą się z rozwojem Nauki 2.0, mediów społecznościowych czy platform naukowych (takich jak Research Gate), oczywiste wydaje się, że zmiany są nieuchronne. Badacze coraz większą wagę przywiązują do widoczności w sieci (Bar-Ilan, 2012) i wykorzystują media społecznościowe na wszystkich etapach cyklu badań naukowych, od identyfikowania potencjalnych współpracowników, przez konsultowanie metod do rozpowszechniania wyników (Nicholas \& Rowlands, 2011; Rowlands et al., 2011; Tenopir et al., 2013). Zmiany następują i można zastanawiać się, kiedy zostaną uwzględnione w nowych systemach oceny i promocji naukowców. Pozostaje tylko pytanie, jaki udział we wprowadzaniu zmian systemowych będą miały różne pokolenia badaczy. Wydaje się, że dużo zależy przede wszystkim od naukowców z ugruntowaną pozycją w nauce, którym nie zagraża już utrata przez lata budowanej pozycji (Harley et al., 2010). Jednakże obserwacja zachowań młodych badaczy w nauce może być ważnym przyczynkiem do określenia kierunków przyszłych zmian systemowych w komunikacji naukowej.

Poniżej przedstawiono cele i organizację badań podjętych w ramach wspomnianego projektu „Harbingers”, a także ogólne wyniki i wnioski z pierwszego ich etapu, zakończonego w 2016 r. Badania empiryczne objęły: Stany Zjednoczone, Chiny, Malezję, a w Europie: Wielką Brytanię, Hiszpanię, Francję i Polskę.

Trzeba mocno podkreślić, że w tym artykule skupiono się jedynie na wybranych aspektach i wynikach badań, a pełniejszą analizę całego przedsięwzięcia czytelnik znajdzie w raporcie z pierwszego etapu badań (CIBER Report, 2016) oraz kilku innych publikacjach zespołu, ilustrujących bliżej niektóre kwestie (Nicholas et al., 2017a, 2017b, 2017c; Rodríguez Bravo et al., 2017). Niniejszy artykuł odróżnia od publikacji zespołu w szczególności mocniejsze zaakcentowanie udziału w badaniach polskich respondentów.

\section{Cele, organizacja i metodyka badań}

Nadrzędnym celem długookresowych badań w ramach projektu „Harbingers” jest prognoza zmian w przyszłej komunikacji naukowej, uwypuklona w tytule międzynarodowego przedsięwzięcia. Zaplanowano trzy roczne fazy projektu (w 2016, 2017 i 2018 roku), po zakończeniu których będzie można stwierdzić, czy i jakie zmiany zaobserwowano oraz czy i jakich zmian można jeszcze oczekiwać. Warto podkreślić, że nikt wcześniej nie prowadził w tym zakresie długookresowych, międzynarodowych badań wśród młodych naukowców, co potwierdził przegląd literatury przedmiotu dokonany w 2015 r. na potrzeby projektu „Harbingers”. Literaturę poddaną analizie w tym przeglądzie wybiórczo przywołano we wprowadzeniu do tego artykułu, natomiast pełny stan badań w interesującym nas zakresie został przedstawiony we wspomnianym raporcie z pierwszego etapu badań (CIBER Report, 2016). W przeglądzie najnowszej literatury również nie znaleziono analogicznych studiów.

Pytania badawcze związane są z wybranymi kwestiami z zakresu komunikacji naukowej, jak m.in.: wykorzystanie mediów społecznościowych i społeczności wirtualnych przez młodych naukowców, zaangażowanie w otwartą naukę, strategia publikowania, recenzowanie i ocenianie, dzielenie się wiedzą i współpraca, budowanie reputacji, a także rola wydawców i bibliotek w komunikacji naukowej (szczegółowe pytania zawarto w raporcie i publikacjach zespołu). To właśnie m.in. w tym obszarach ściśle związanych z Nauką 2.0, 
jak stwierdzono na podstawie światowej literatury przedmiotu, można spodziewać się pewnych zmian.

W badaniach wykorzystano metody jakościowe i ilościowe. Metody jakościowe obejmują wywiady indywidualne, pogłębione, z wykorzystaniem znormalizowanego kwestionariusza obejmującego łącznie 12 tematycznych grup pytań-dyspozycji. Obok zagadnień wyżej wymienionych zbierane są też informacje o dorobku naukowym i przebiegu kariery respondentów. Oprócz rozmów bezpośrednich wywiady prowadzone są także za pomocą Skype'a oraz telefonicznie. Grupą badaczy w projekcie „Harbingers” pochodzących z sześciu krajów kieruje David Nicholas (dyrektor niezależnego ośrodka badawczego CIBER Research), a w jej skład wchodzą: Anthony Watkinson i Eti Herman (także pracownicy CIBER Research, Wielka Brytania), Cherifa Boukacem-Zeghmouri (Université Claude Bernard Lyon 1, Francja), Blanca Rodríguez Bravo (Universidad de León, Hiszpania), Jie Xu (Wuhan University, Chiny), Abrizah Abdullah (University of Malaya, Malezja) i Marzena Świgoń (Uniwersytet Warmińsko-Mazurski w Olsztynie, Polska). Wymienieni badacze przeprowadzają wywiady z respondentami. W zależności od kraju wywiady są prowadzone w języku angielskim lub językach narodowych, a następnie tłumaczone na język angielski. Na potrzeby badań przygotowany został specjalny rodzaj kodowania otrzymanych odpowiedzi, czyli zestaw wskazówek, pomocniczych pytań i kwestii, na które prowadzący wywiady mają zwrócić uwagę oraz umowne symbole cyfrowe ułatwiające klasyfikowanie odpowiedzi respondentów. Trzeba powtórzyć, że opis tego narzędzia, jak i całej metodologii badań, jest dostępny w sieci w przywoływanym wcześniej raporcie.

W badaniach ilościowych wykorzystano wyżej wspomniany system kodowania (CIBER Report, 2016, 67). Analizy statystyczne polegały na obliczaniu odsetków odpowiedzi danego rodzaju, co z kolei umożliwia do pewnego stopnia, zważywszy na różnice kulturowe i w polityce naukowej różnych krajów, porównania w zakresie płci respondentów, statusu, rodzaju nauk czy pomiędzy krajami, choć z dużymi ograniczeniami. Dlatego należy podkreślić, że analizy ilościowe pełnią tylko uzupełniającą rolę, drugorzędną w porównaniu $\mathrm{z}$ analizą interpretatywną, która wynika z dominującego jakościowego charakteru podjętych badań i ograniczonej próby badawczej.

W pierwszej fazie wywiadów udział wzięło łącznie 116 młodych naukowców z siedmiu krajów. Dokładny rozkład respondentów przedstawiono w tabeli 1.

Tab. 1. Udział respondentów z siedmiu krajów w badanej zbiorowości młodych naukowców (źródło: http://ciber-research.eu/harbingers.html)

\begin{tabular}{|l|c|c|}
\hline \multicolumn{1}{|c|}{ Kraj } & Liczba respondentów & Odsetek w próbie badawczej \\
\hline Stany Zjednoczone & 28 & 24.1 \\
\hline Wielka Brytania & 21 & 18.1 \\
\hline Hiszpania & 18 & 15.5 \\
\hline Francja & 14 & 12.1 \\
\hline Chiny & 13 & 11.2 \\
\hline Malezja & 12 & 10.3 \\
\hline Polska & 10 & 8.6 \\
\hline Razem & 116 & 100.0 \\
\hline
\end{tabular}


Wszystkich młodych pracowników nauki łączyło mniejsze lub większe doświadczenie w pracy badawczej i projektowej (chodziło o udział w projektach badawczych w przeszłości i/lub w trakcie badań). Większość respondentów (76\%) miała doktoraty, zdecydowanie mniejszą część całej próby stanowili doktoranci (24\%), ale wśród respondentów z Polski proporcje te rozłożyły się równomiernie (po 50\%). Dziesięciu polskich respondentów związanych było (w okresie prowadzenia wywiadów) z Uniwersytetem Warmińsko-Mazurskim w Olsztynie. W całej badanej zbiorowości większość młodych badaczy (urodzonych w latach 1982-1994) przekroczyła 30. rok życia (69\%), co dotyczyło też respondentów z Polski (60\%). Mężczyźni przeważali zarówno w całej próbie (58\%), jak i w grupie polskich respondentów (60\%).

Uczestnicy wywiadów reprezentowali różne dyscypliny naukowe, jednak przeważnie nauki ścisłe i biologiczne (75.8\%), rzadziej nauki społeczne (24.2\%); dokładny rozkład przedstawiono $\mathrm{w}$ tabeli 2. Polscy respondenci związani byli w zdecydowanej większości (80\%) z naukami biologicznymi i rolniczymi oraz inżynieryjnymi i technicznymi, tylko dwoje reprezentowało nauki społeczne.

Tab. 2. Udział respondentów z różnych dyscyplin w badanej zbiorowości młodych naukowców (źródło: http://ciber-research.eu/harbingers.html)

\begin{tabular}{|l|c|c|}
\hline \multicolumn{1}{|c|}{ Rodzaj nauk } & Liczba respondentów & Odsetek w próbie badawczej \\
\hline Nauki biologiczne, rolnicze & 25 & 21.6 \\
\hline Nauki medyczne i o zdrowiu & 15 & 12.9 \\
\hline Nauki inżynieryjne i techniczne & 12 & 10.3 \\
\hline Chemia & 10 & 8.6 \\
\hline Informatyka & 10 & 8.6 \\
\hline Psychologia & 6 & 5.2 \\
\hline Inne nauki społeczne & 22 & 19.0 \\
\hline Inne nauki ścisłe & 8 & 6.9 \\
\hline Razem & 116 & 100.0 \\
\hline
\end{tabular}

W kolejnej części artykułu scharakteryzowano niektóre obserwacje poczynione w pierwszej fazie badań, czyli podczas wywiadów przeprowadzonych w 2016 r. Pełniejszy opis uzyskanych rezultatów znajduje się w przywołanych we wprowadzeniu raporcie i publikacjach zespołu (prace opublikowane zawarto w bibliografii, inne pozostają w druku).

Dokonując wyboru wyników badań prowadzonych w ramach międzynarodowego projektu „Harbingers”, autorzy artykułu mieli na uwadze nie tylko troskę o niepowtarzanie omawiania rezultatów opublikowanych w języku angielskim, ale przede wszystkim skupienie uwagi na wynikach uzyskanych w badaniach prowadzonych na polskich respondentach oraz porównaniu ich z wynikami uzyskanymi dla całej, międzynarodowej próby. Celem artykułu jest też rozpropagowanie wyników rozpoczętych badań wśród polskich czytelników (temu służyła też prezentacja omawianego tu tematu na konferencji „Nauka o informacji (informacja naukowa) w okresie zmian", zorganizowanej w Warszawie przez Katedrę Informatologii Wydziału Dziennikarstwa, Informacji i Bibliologii Uniwersytetu 
Warszawskiego w maju 2017 r. $)^{1}$. Tak więc poniższa część niniejszego artykułu poświęcona wynikom zespołowych badań, jest służącym tym celom wyborem dokonanych obserwacji i wyciągniętych wniosków.

\section{Wybrane rezultaty i wnioski z pierwszego etapu badań $\mathrm{z}$ akcentem na polskich respondentów}

Zdecydowana większość ze 116 respondentów, którzy wzięli udział w wywiadach w pierwszej fazie badań, będąc na czasowym kontrakcie bądź studiach doktoranckich, bardzo chciałaby znaleźć stałe zatrudnienie w instytucji naukowo-badawczej (ang. tenure). Dotyczyło to także polskich respondentów, z których tylko jedna osoba (10\%) wiązała przyszłość z przemysłem, a nie z uczelnią. Większość (ogółem oraz w polskiej grupie) podkreślała swoje duże zainteresowanie pracą naukową i podjętą tematyką badawczą, wskazując je jako główną motywację zaangażowania w działalność naukową (w porównaniu do innego rodzaju motywacji, np. finansowej).

Z uzyskanych odpowiedzi w siedmiu krajach wynikało jasno, że najważniejszą częścią pracy naukowej jest dla młodych badaczy publikowanie wyników w czasopismach posiadających wskaźnik wpływu Impact Factor (IF) lub innych uznanych w danym środowisku lub dyscyplinie za prestiżowe. Jak wspomniano we wprowadzeniu, współcześni prekariusze nauki są mocno skoncentrowani na budowaniu swojej reputacji w oparciu właśnie o publikacje w renomowanych czasopismach, wierząc przy tym, że to one są gwarantem rozwoju ich przyszłej kariery. Z uzyskanych odpowiedzi w międzynarodowej grupie wynika, że niekiedy nie chodzi tylko o zasadę „publikuj albo giń" (ang. "publish or perish”) ani nawet o publikowanie w czasopismach z IF. Celem młodych badaczy jest publikowanie w czasopismach z jak najwyższym IF (sic!). Taka postawa była widoczna częściowo także w polskiej grupie, a ściślej wśród osób z doktoratami z nauk ścisłych i przyrodniczych. Dla przykładu, jedna z polskich respondentek wspomniała, że nie jest zadowolona z artykułów za dwadzieścia kilka punktów, pragnie raczej tych za czterdzieści.

Tak więc w kontekście poszukiwania oznak zmian w komunikacji naukowej i stwierdzając wyraźne nastawienie młodych badaczy na publikowanie w czasopismach z różnego rodzaju rankingów, uznać można całą międzynarodową zbiorowość respondentów raczej za naśladowców czy konserwatystów niż innowatorów. W odniesieniu do polskiego środowiska badaczy, także mocno skoncentrowanych na publikowaniu, należy dopowiedzieć, że trend publikowania na ministerialnej liście A, czyli w czasopismach rejestrowanych w bazie Web of Science, nie jest jeszcze wiodący, a przynajmniej nie dominuje w naukach humanistyczno-społecznych. Ponadto sama wysokość współczynnika IF była dużo bardziej ważna dla respondentów z Wielkiej Brytanii, Stanów Zjednoczonych, Francji i Hiszpanii niż tych z pozostałych krajów, czyli, oprócz Polski, także w Malezji i Chinach. Oczywiście, z jednej strony pewne znaczenie ma tutaj fakt istnienia w niektórych krajach preferowanych przez rząd list czasopism, ale z drugiej strony, takie listy tworzone są m.in. w oparciu o Journal Citations Reports, czyli bazę danych o znaczeniu globalnym.

\footnotetext{
${ }^{1}$ Sprawozdanie z IV Międzynarodowej Konferencji „Nauka o informacji (informacja naukowa) w okresie zmian: Innowacyjne usługi informacyjne” opublikowane zostało w ZIN 2017, 55 (1), 181-185 [red.].
} 
Respondenci z projektu „Harbingers” okazali się płodnymi autorami, ponieważ każdy średnio opublikował do czasu wywiadu około 10 artykułów w czasopismach oraz sześciu tekstów w tomach pokonferencyjnych, a łącznie było to ponad 1200 tekstów w grupie 116 młodych badaczy. Zróżnicowanie w każdej grupie narodowej było dość duże, a w polskiej grupie zdarzyły się osoby z kilkudziesięcioma publikacjami, jak i bez żadnego opublikowanego tekstu (ta ostatnia sytuacja dotyczyła najmłodszych doktorantów, którzy zgłosili swoje teksty do druku).

W całej badanej populacji międzynarodowej nie było widać symptomów zmiany w odniesieniu do wiodącej od dawna pozycji artykułu w renomowanym czasopiśmie, jako podstawowym kanale formalnej komunikacji naukowej. Do specyfiki wyników uzyskanych w wywiadach prowadzonych z polskimi respondentami dodać jednak należy, że część ich dorobku stanowiły artykuły w krajowych czasopismach uwzględnionych w ministerialnej liście $\mathrm{B}, \mathrm{w}$ języku polskim, więc właściwie nieobecnych w międzynarodowej komunikacji naukowej. Wagę podobnych list czasopism uznawanych (przez ministerstwo lub uczelnię) widać było w odpowiedziach nie tylko polskich respondentów, ale także chińskich i malezyjskich. Trzeba jednak dodać, że we wszystkich nieanglojęzycznych krajach uwzględnionych w badaniach publikowanie w języku angielskim jest normą, jeśli nie priorytetem.

Wypatrując zmian w przyszłej komunikacji naukowej wydawać by się mogło, że pozycja czasopism w otwartym dostępie (ang. Open Access journals) powinna być szczególnie wysoka wśród nowej generacji badaczy. Niestety, uzyskane wyniki - tak ogółem, jak i w polskiej grupie - w ogóle tego nie potwierdziły. Generalnie najważniejszym kryterium doboru czasopisma był dla respondentów nie otwarty dostęp, a indeksowanie w bazach: Web of Science, Scopus lub obecność na krajowych listach czasopism. W świetle wypowiedzi młodych naukowców o publikowaniu w otwartym dostępie można powiedzieć, że ich postawy wobec tej drogi komunikacji naukowej są bardzo pozytywne. Jednak zachowania młodych badaczy w tym zakresie nie są już innowacyjne, tzn. w wyborze czasopisma do publikacji swoich prac respondenci nie kierowali się zasadą otwartego dostępu. Wynika to z pewnością ze specyfiki systemów formalnej komunikacji naukowej oraz obowiązujących kryteriów oceniania badań naukowych i zasad ich finansowania. Z wyjątkiem Wielkiej Brytanii i Stanów Zjednoczonych, gdzie złota droga otwartego dostępu wspierana jest przez rządy państw i fundatorów badań, w pozostałych krajach publikowanie w otwartym dostępie - przynajmniej w świetle uzyskanych odpowiedzi - nie należy do priorytetów ani nie jest wyznacznikiem strategii publikacyjnej młodych naukowców. Zresztą także dla respondentów z Wielkiej Brytanii i Stanów Zjednoczonych priorytetem jest raczej, jak wcześniej powiedziano, obecność czasopisma w Journal Citation Reports i wysokość wskaźnika IF.

Publikowanie dużej liczby artykułów indeksowanych w WoS jest dużo łatwiejsze, jeśli pracuje się w grupach projektowych, często wirtualnych, w które zaangażowana była część badanych w różnych krajach, w tym w Polsce. Ponadto bycie członkiem takiej grupy, szczególnie na poziomie międzynarodowym, wpływało znacząco zdaniem respondentów na budowanie prestiżu w nauce, a w niektórych krajach było ściśle związane z ofertami zatrudnienia. Na przykład młodzi naukowcy z Francji twierdzili zgodnie, że nie tylko publikacje, ale także szeroka międzynarodowa współpraca wpływa pozytywnie na ich karierę zawodową. Co ciekawe, wśród polskich respondentów, zarówno w naukach przyrodniczych, jak i społecznych, niebędących członkami takich międzynarodowych zespołów, wyraźnie widać było ową potrzebę znalezienia zagranicznych partnerów do badań. 
Zdecydowana większość badanych przyznała też, że dla budowania prestiżu i pozycji w świecie nauki ważne jest, oprócz publikowania artykułów w renomowanych czasopismach, także dzielenie się wiedzą w sieci, w mediach społecznościowych, na platformach społeczności wirtualnych, np. Research Gate. Owo dzielenie się wiedzą było jednak dosyć wąsko pojmowane, w dużej mierze ograniczało się bowiem do aktywności w sieci „po publikacji".

Do mediów społecznościowych najczęściej wykorzystywanych przez badanych 116 respondentów należały: Research Gate (RG) - cieszące się największą popularnością we wszystkich siedmiu krajach, LinkedIn i Twitter - wykorzystywane w porównaniu do RG rzadziej i nie we wszystkich krajach. Wykorzystywanie social media polegało na ogół na udostępnianiu własnych tekstów lub informowaniu o ich publikacji. Przed ukazaniem się (bądź przyjęciem do druku) oficjalnej publikacji (w czasopiśmie) raczej nie dzielono się - w szerokim zakresie - nową wiedzą i informacjami. Innymi słowy, media społecznościowe były przez respondentów wykorzystywane do dzielenia się nowymi pomysłami czy wynikami trwających badań, ale tylko w wąskich grupach projektowych czy z najbliższymi współpracownikami.

Natomiast dosyć powszechnie wykorzystywano ogromny potencjał mediów społecznościowych związany z rozpowszechnianiem opublikowanych (w czasopismach i książkach) tekstów, a także z szukaniem i pozyskiwaniem informacji (informacji o publikacjach i pdf-ów). W polskiej grupie w pierwszym roku prowadzenia badań siedmiu respondentów (70\%) było aktywnymi użytkownikami Research Gate, tzn. posiadało konta ze zdjęciem oraz udostępniało swoje teksty, jak też korzystało z tekstów tam udostępnianych. Dla porównania tylko trzech (30\%) używało serwisu Academia.edu. Podobną dużą przewagę korzystania z Research Gate w porównaniu do Academia.edu zaobserwowano też wśród respondentów z pozostałych sześciu krajów.

Z innych mediów społecznościowych w komunikacji naukowej pewne znaczenie ma, jak wspomniano, Twitter oraz LinkedIn, głównie w Stanach Zjednoczonych, Wielkiej Brytanii oraz Hiszpanii, mniej w Chinach i Malezji. Co charakterystyczne, Twitter oraz LinkedIn nie był używany przez respondentów z Polski i Francji; za to tylko w tych krajach wspomniano o YouTube. O Facebooku w kontekście pozyskiwania informacji wspomniano jedynie w Stanach Zjednoczonych i w Hiszpanii, a o Wikipedii tylko w Malezji.

W pozyskiwaniu informacji naukowej prym wiedzie, w świetle udzielonych odpowiedzi, Google, Google Scholar, Web of Science oraz Scopus (w naukach medycznych PubMed), jak też Research Gate. Wspomnieć trzeba o różnicach politycznych widocznych w odpowiedziach, np. chińscy respondenci twierdzili, że preferują krajowe źródła i komunikatory, co można traktować jako pewną postawę nacechowaną politycznie.

Repozytoria nie cieszyły się zbyt dużym zainteresowaniem w badanej grupie młodych naukowców, choć wydawać mogłoby się, że będą chcieli je wykorzystywać jako dobrą okazję do zwiększenia swojej widoczności w sieci. Abstrahując od różnic narodowych i w obrębie dyscyplin, można powiedzieć, że młodzi badacze umieszczają w nich swoje teksty, jeśli jest to obligatoryjne. Niektórzy twierdzili, że sami nie przeglądają ich zawartości, inni przyznawali się nawet, że nie orientują się, czy ich instytucja takowe prowadzi. Polscy respondenci nie byli tu wyjątkiem. Wprawdzie UWM nie posiada instytucjonalnego repozytorium, ale respondenci nie wskazywali też na korzystanie z innych repozytoriów. Ogółem respondenci z siedmiu krajów podkreślali, że najważniejsze dla nich jest archiwizowanie swoich 
tekstów na Research Gate, doceniali też tę platformę jako miejsce poszukiwania pełnych tekstów z interesującego ich zakresu.

Uczestniczący w badaniach młodzi naukowcy generalnie okazali się nie być entuzjastami idei otwartej nauki. Niektórzy nawet nie byli zbyt dobrze zorientowanych co dokładnie wchodzi w zakres tego pojęcia. Jak już wspomniano, młodzi naukowcy nie byli zaangażowani w publikowanie w czasopismach w otwartym dostępie (ang. open access), w żadnym razie nie czynili z tego strategii publikacyjnej. Ponadto raczej nie byli zaangażowani w udostępnianie danych z własnych badań (ang. open data), ani w prowadzenie blogów.

Wskaźniki altmetryczne także wydają się jeszcze nie mieć dla przedstawicieli badanego pokolenia zbyt dużego znaczenia. Większość podkreślała, że głównym ograniczeniem tego rodzaju danych jest fakt, że nie są brane pod uwagę $w$ ich uczelniach w procesie formalnej oceny ich pracy. Jednakże niektórzy przyznali, że niekiedy zwracają uwagę na liczbę ściągnięć czy udostępnień. Stwierdzili też, że wskaźniki te mają pewien potencjał w określaniu oddziaływania czy wpływu (ang. impact) danej publikacji lub autora. Jednak większość utożsamiała taki wpływ raczej z tradycyjnymi cytowaniami wynikającymi z publikowania tekstów w wysoko punktowanych czasopismach. Szczególne miejsce zajmują tu badacze z Wielkiej Brytanii, którzy zobligowani swoim systemem Research Excellence Framework, muszą nie tylko publikować w renomowanych czasopismach, ale także walczyć o szerokie oddziaływanie w społeczeństwie, do czego wykorzystują przeróżne środki, w tym m.in. media społecznościowe.

Pewnym zaskoczeniem w uzyskanych rezultatach było stosunkowo niewielkie korzystanie przez respondentów ze smartfonów w dzieleniu się informacją naukową. Zważywszy na popularność tego urządzenia w pokoleniu młodych osób, spodziewano się szerszego ich wykorzystywania do celów naukowych. Tymczasem okazało się, że nawet respondenci podłączeni do sieci przez całą dobę wykorzystują smartfony raczej do celów prywatnych, nie czytają pełnych tekstów naukowych, rzadko przeglądają nawet abstrakty. Najbardziej wykorzystywali je Chińczycy, a najmniej Polacy, tylko trzech polskich respondentów okazało się użytkownikami smartfonów do celów naukowych.

Innym ważnym aspektem badań była próba określenia przyszłej roli bibliotek naukowych w komunikacji naukowej i w pozyskiwaniu informacji naukowej. Trzeba przyznać, że respondenci, choć korzystali z platform bibliotecznych, nie przywiązywali zbyt dużej wagi do samego istnienia bibliotek, szczególnie w obliczu systematycznego korzystania z Google Scholar i Research Gate. Pewnym wyjątkiem okazali się tu polscy respondenci, którzy w przeważającej większości (osiem osób) przewidywali, że biblioteki będą nadal pełnić ważną rolę i byli świadomi, że dostęp do wielu baz, w tym Web of Science, mają poprzez stronę biblioteki uczelnianej. Ogółem jednak, dla międzynarodowej społeczności biblioteki stają się coraz bardziej niewidoczne.

Odrębną kwestią była przyszła rola platform wydawców. Chociaż młodzi pracownicy nauki bazują na czasopismach, rzadko wiedzą, kto jest wydawcą preferowanych przez nich tytułów i jeszcze rzadziej odwiedzają ich strony w celu znalezienia potrzebnej im informacji naukowej (regularnie korzystają z przewodników dla autorów). Nazwy wydawców pojawiły się w tym kontekście w wypowiedziach jedynie 13 ze 116 respondentów.

Projekt „Harbingers” oparty został na badaniach o charakterze jakościowym, jednak zebrany materiał po skategoryzowaniu odpowiedzi umożliwił przeprowadzenie również pewnych analiz ilościowych z wykorzystaniem metod statystycznych. 
W badaniach testowano 26 hipotez (ich wykaz znajduje się w CIBER Report (2016, 62-66), które sformułowano na podstawie przeglądu literatury i konsultacji w środowisku badaczy komunikacji naukowej. Otrzymane wyniki ilustrowały m.in. podobieństwa i różnice pomiędzy odpowiedziami respondentów z różnych krajów (Rys. 1).

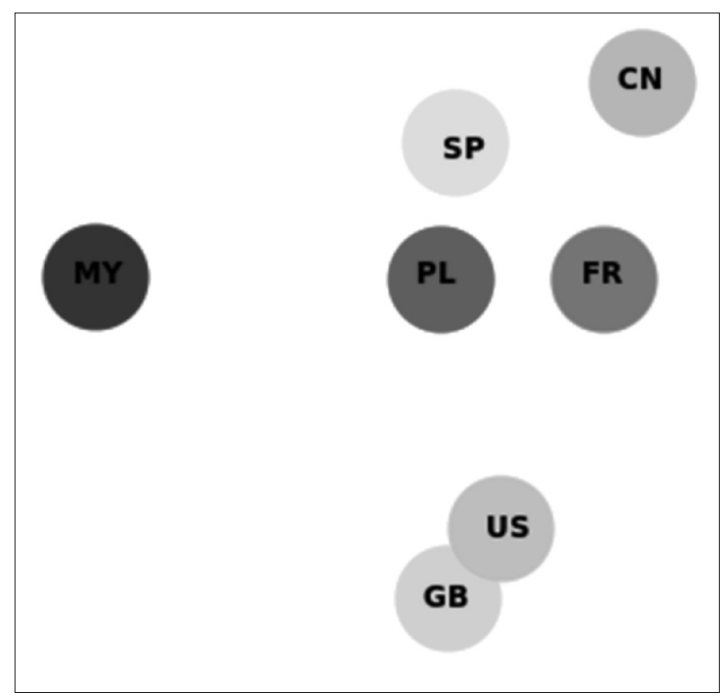

Rys. 1. Podobieństwa i różnice pomiędzy odpowiedziami respondentów z różnych krajów (źródło: http://ciber-research.eu/harbingers.html)

Analizując schemat przedstawiony na rysunku 1, nie sposób nie zwrócić uwagi na centralną pozycję symbolu PL. Świadczy to przede wszystkim o największej liczbie wspólnych cech w postawach i zachowaniach młodych polskich badaczy i badaczy z pozostałych sześciu krajów, w tym szczególnie z Hiszpanii. Wzajemna bliskość Stanów Zjednoczonych i Wielkiej Brytanii wydaje się oczywista, podobnie jak ich odległość od Chin czy Malezji oraz pomiędzy tymi krajami. Warto jeszcze raz podkreślić, że różnice narodowościowe są w całej metodologii badań drugorzędne, zbyt małe były bowiem liczebności grup narodowych, aby wyciągać uogólnione wnioski.

Niemniej warto dodać, że ogółem $20 \%$ z testowanych hipotez zostało potwierdzonych i $20 \%$ odrzuconych. Tylko dwie hipotezy zostały potwierdzone we wszystkich siedmiu krajach:

- Środowisko, w którym pracują młodzi naukowcy, jest prekariackie;

- młodzi pracownicy nauki preferują system anonimowych koleżeńskich recenzji (ang. double blind peer review) jako najbardziej sprawiedliwych.

Kolejne trzy hipotezy zostały potwierdzone lub częściowo potwierdzone w siedmiu krajach:

- dopóki akademicy będą w tradycyjny sposób zatrudniani, oceniani i finansowani na podstawie głównie listy publikacji i wskaźnika cytowań, nie będzie możliwa zmiana zachowań związanych z komunikacją naukową;

- młodzi pracownicy nauki podporządkowują się zastanym zasadom w komunikacji naukowej; 
- $\quad$ młodzi pracownicy nauki, którzy są zainteresowani zdobywaniem kolejnych szczebli kariery naukowej, czują się „niewolnikami” metrycznego (punktowego) systemu oceny ich pracy, ściśle związanego z publikowaniem w renomowanych czasopismach.

Dwie hipotezy zostały odrzucone we wszystkich uwzględnionych w badaniach krajach:

- młodzi pracownicy nauki publikują w czasopismach w otwartym dostępie, ponieważ łatwiej jest się do nich dostać;

- młodzi pracownicy nauki są zainteresowani bardziej mediami społecznościowymi i wskaźnikami altmetrycznymi niż tradycyjnymi cytowaniami, na które trzeba bardzo długo czekać.

Wiele było też widocznych różnic w zachowaniach respondentów pochodzących z poszczególnych krajach, o niektórych wspomniano już w tym artykule. Jednakże przytoczone powyżej potwierdzone i odrzucone hipotezy pokazują, jak wiele przede wszystkim łączy młodych reprezentantów różnych nauk z różnych państw. Wszędzie borykają się z podobnymi problemami funkcjonowania w prekariackim i konkurencyjnym środowisku. Dostosowują się do zastanego systemu, ponieważ najbardziej zależy im na utrzymaniu się na obranej ścieżce kariery, która zgodna jest z ich zainteresowaniami i ambicjami. Nie planują rewolucji, ponieważ nie czują, że mogą coś zmienić. Raczej koncentrują się na spełnianiu stawianych im wymagań, chociaż podkreślają, że są one zbyt wygórowane.

Kończąc prezentację wybranych rezultatów projektu „Harbingers”, trzeba wspomnieć o ograniczeniach rozpoczętego cyklu tych międzynarodowych badań. Jednym z nich jest zasadniczo niewielka grupa respondentów, która nie pozwala na uogólnianie wyników na całe pokolenie młodych badaczy, nawet gdyby poszerzyć lub zawęzić umownie przyjętą definicję (doktoranci i doktorzy do 35 lat). Reprezentacje poszczególnych krajów w próbie badawczej również są niewystarczające do wyciągania wniosków o charakterze cech narodowych ani o narodowych systemach komunikacji naukowej. W każdym kraju w obrębie różnych uczelni i dyscyplin mogą występować znaczące różnice, które nie są w podjętych badaniach brane pod uwagę. Wydaje się jednak, że pionierski zamysł zespołu „Harbingers”, polegający na długookresowych (a rozważane jest przedłużenie czasu badań z trzech lat do pięciu) obserwacjach tych samych młodych naukowców, śledzenia ich losów w świecie nauki i sprawdzania opinii o kluczowych dla komunikacji naukowej kwestiach, może zaowocować ciekawymi wynikami i ważnymi wnioskami (chociażby w obliczu aktualnie dyskutowanej reformy polskiej nauki).

\section{Zakończenie}

Z przeprowadzonych międzynarodowych badań, a ściślej pierwszej z trzech zaplanowanych ich części (CIBER Report, 2016; Nicholas et al., 2017abc; Rodríguez Bravo et al., 2017 i inne publikacje zespołu w druku), których wycinkową i fragmentaryczną charakterystykę zaprezentowano w tym artykule, wynika, że choć młodzi pracownicy nauki widzą możliwości zmiany systemu komunikacji naukowej, nie korzystają z nich w takim stopniu jak można by się spodziewać.

Możliwości te są związane, jak wspomniano we wprowadzeniu, przede wszystkim z rozwojem nowoczesnych technologii, mediów społecznościowych i wskaźników altmetrycznych, z ideą otwartego dostępu do informacji naukowej i otwartej nauki. Niestety, nie idą 
one w parze ze zmianami systemu finansowania i oceniania pracy badawczej, a właściwie systemów w różnych krajach, nie tylko tych uwzględnionych w projekcie „Harbingers”.

W ubieganiu się o granty wciąż ważne są tradycyjne sposoby oceniania potencjału badaczy, czyli publikacje w najbardziej prestiżowych czasopismach oraz tradycyjne cytowania. Presja związana z takimi publikacjami, powiązana z nadmiarem innych obowiązków zawodowych, a także z niepewnością wynikającą z warunków zatrudnienia (prekariusze) na ogół nie sprzyjają zainteresowaniu młodych naukowców mniej formalnymi aktywnościami naukowymi, nie przekładającymi się bezpośrednio na ich ocenianie. Tymczasem prowadzenie blogów naukowych, dyskusji na forach jest niezwykle ważne dla idei otwartej nauki i edukacji, a ponieważ jest bardzo czasochłonne i na ogół nie liczy się w ocenie, niewielu badaczy bierze aktywny w nich udział.

Jednakże były w badanej międzynarodowej grupie osoby, które pragną zmian w komunikacji naukowej i nawet deklarują w tym zakresie swoje zaangażowanie, ale dopiero kiedy zdobędą pozycję lub stanowisko umożliwiające bardziej ryzykowne postawy i zachowania, a co za tym idzie wprowadzanie zmian. W tym kontekście polscy respondenci mieli świadomość ogromnej międzynarodowej konkurencji i konieczności pewnych reform w polskim systemie szkolnictwa wyższego (zwracali uwagę m.in. na długą drogę do samodzielności naukowej). Niektórzy przyznali się do marzeń o zatrudnieniu w zachodnich uczelniach, które postrzegali jako bardziej sprzyjające pracy naukowej (wystarczy doktorat) i byli świadomi, że teraz muszą przede wszystkim budować swoją reputację w oparciu o publikacje indeksowane w Web of Science i Scopus.

Patrząc jednak globalnie, a przynajmniej na kraje uwzględnione w niniejszych badaniach, można na zakończenie tylko powtórzyć, że w każdym z nich panuje duża konkurencja i niepewność wśród młodych badaczy.

Być może wywiady w kolejnych latach przyniosą wyraźniejszy obraz zmian, jakich możemy się spodziewać w przyszłej komunikacji naukowej.

\section{Źródło finansowania i współpracownicy:}

Projekt Harbingers jest finansowany przez Publishing Research Consortium, a realizowany przez CIBER Research Ltd. Do pozostałych współpracowników, obok autorów artykułu, należą: Anthony Watkinson, Cherifa Boukacem-Zeghmouri, Abrizah Abdullah, Blanca Rodríguez Bravo, Jie Xu i Eti Herman.

\section{Bibliografia}

Bar-Ilan, J., Haustein, S., Peters, I., Priem, J., Shema, H. and Terliesner, J. (2012). Beyond Citations: Scholars' Visibility on the Social Web [online]. arXiv preprint, [22.12.2017],. arXiv:1205.5611.

Bazeley, P. (2003). Defining Early Career in Research. Higher Education, 45(3), 257-79.

Bennion, A., Locke, W. (2010). The Early Career Paths and Employment Conditions of the Academic Profession in 17 Countries. European Review, 1These 8(S1), S7-S33.

Brechelmacher, A., Park, E., Ates, G., Campbell, D. F. (2015). The Rocky Road to Tenure-Career Paths in Academia. In: T. Fumasoli, G. Goastellec, B.M. Kehm (eds.) Academic Work and Careers in Europe: Trends, Challenges, Perspectives (13-40). Springer International Publishing.

Bridle, H., Vrieling, A., Cardillo, M., Araya, Y., Hinojosa, L. (2013). Preparing for an Interdisciplinary Future: A Perspective from Early-Career Researchers. Futures, 53, 22-32. 
CIBER Report (2016). Early Career Researchers: The Harbingers of Change? [online]. Final Report CIBER, Year 1, [9.10.2017], http://ciber-research.eu/download/20161120-ECR_Year_1_final_report_071116.pdf

Corkery, C., Mitchell, J., Walker, V., Annan, R., Goel, N., Harvey, L., ... Vilches, S. L. (2013). The 2013 Canadian Postdoc Survey: Painting a Picture of Canadian Postdoctoral Scholars [online]. CASP-ACSP and Mitacs [26.12.2017], https://www.mitacs.ca/sites/default/files/caps-mitacs_postdoc_report-full_oct22013-final.pdf

Fransman, J. (2014). Becoming Academic in the Digital Age: Negotiations of Identity in the Daily Practices of Early Career Researchers [online]. Connected Communities and Early Career Researchers Workshop, City University, May 2014, [9.10.2017], https://www.srhe.ac.uk/downloads/ FRANSMAN_Final_Report.pdf

Friesenhahn, I., Beaudry, C. (2014). The Global State of Young Scientists - Project Report and Recommendations. Berlin: Akademie Verlag.

Graham, H., Hill, K., Matthews, P., O’Brien, D.,Taylor, M. (2014). Connecting Epistemologies: Methods and Early Career Researchers in the Connected Communities Programme [online]. [9.10.2017], https://earlycareerresearchers.files.wordpress.com/2014/10/connecting-epistemologies-report.pdf

Harley, D., Acord, S.K., Earl-Novell, S., Lawrence, S., King, C.J. (2010). Assessing the Future Landscape of Scholarly Communication: An Exploration of Faculty Values and Needs in Seven Disciplines [online]. UC Berkeley: Center for Studies in Higher Education. [9.10.2017], https://escholarship. org/uc/item/15x7385g

Housewright, R., Schonfeld, R. C., Wulfson, K. (2013). Ithaka S+R US Faculty Survey 2012 [online]. Ithaka S+R [26.12.2017], http://www.sr.ithaka.org/wp-content/uploads/2015/08/Ithaka_SR_US_Faculty_Survey_2012_FINAL.pdf

James, L., Norman, J., De Baets, A. S., Burchell-Hughes, I., Burchmore, H., Philips, A., Sheppard, D., Wilks, L., Wolffe, J. (2009). The Lives and Technologies of Early Career Researchers [online]. JISC; CARET, University of Cambridge; The Open University, UK. [9.10.2017], http://www.webarchive.org.uk/wayback/archive/20140614204612/http://www.jisc.ac.uk/publications/reports/2009/ earlycareerresearchersstudy.aspx

Müller, R. (2014a). Racing for What? Anticipation and Acceleration in the Work and Career Practices of Academic Life Science Postdocs. Forum Qualitative Sozialforschung / Forum: Qualitative Social Research [online], 15(3), [22.12.2017], http://www.qualitative-research.net/index.php/fqs/article/view/2245

Müller, R. (2014b). Postdoctoral Life Scientists and Supervision Work in the Contemporary University: A Case Study of Changes in the Cultural Norms of Science. Minerva, 52(3), 329-349.

Mulligan, A., Mabe, M. (2011). The Effect of the Internet on Researcher Motivations, Behaviour and Attitudes. Journal of Documentation, 67(2), 290-311.

Nicholas, D., Rowlands, I. (2011). Social Media Use in the Research Workflow. Information Services and Use, 31(1-2), 61-83.

Nicholas, D., Boukacem-Zeghmouri Ch., Rodríguez-Bravo, B., Xu, J., Watkinson, A., Abrizah, A., Herman, E., Świgoń, M. (2017a). Where and How Early Career Researchers Find Scholarly Information. Learned Publishing, 30(1), 19-29.

Nicholas, D., Jamali, H. R., Watkinson, A., Herman, E., Tenopir, C., Volentine, R., Allard, S., Levine, K. (2015a). Do Younger Researchers Assess Trustworthiness Differently When Deciding What to Read and Cite and Where to Publish? International Journal of Knowledge Content Development and Technology, 5(2), 45-63.

Nicholas, D., Herman, E., Jamali, H.R. (2015b). Analysis of Emerging Reputation Mechanisms for Scholars [online]. In: R. Vuorikari \& Y. Punie (eds.). Analysis of Emerging Reputation and Funding Mechanisms in the Context of Open Science 2.0 (3-72). Part 1. European Commission, Joint Research Centre, Institute for Prospective Technological Studies. [9.10.2017], http://publications. jrc.ec.europa.eu/repository/bitstream/JRC94952/jrc94952.pdf 
Nicholas, D., Rodríguez Bravo, B., Watkinson, A., Boukacem-Zeghmouri, Ch., Herman, E., Xu, J., Abrizah, A., Świgoń, M. (2017c). Early Career Researchers: Their Publishing and Authorship Practices. Learned Publishing, 30(3), 205-217.

Nicholas, D., Watkinson, A., Boukacem-Zeghmouri, Ch., Rodríguez Bravo, B., Xu, J., Abrizah, A., Świgoń, M., Herman, E. (2017b). Early Career Researchers: Scholarly Behaviour and the Prospect of Change. Learned Publishing, 30(2), 157-166.

Rodríguez Bravo, B., Nicholas, D., Herman, E., Boukacem-Zeghmouri, Ch., Watkinson, A., Abrizah, A., Xu, J., Świgoń, M. (2017). Peer Review: the Experience and Views of Early Career Researchers. Learned Publishing 30(4), 269277.

Rowlands, I., Nicholas, D., Russell, B., Canty, N., Watkinson, A. (2011). Social Media Use in the Research Workflow. Learned Publishing, 24(3), 183-195.

Teichler, U., Cummings, W. K. (2015). Forming, Recruiting and Managing the Academic Profession: A Varied Scene. In: Teichler, U., \& Cummings, W. K. (eds) Forming, Recruiting and Managing the Academic Profession (1-10). Springer International Publishing.

Tenopir, C., Volentine, R., King, D. (2013). Social Media and Scholarly Reading. Online Information Review, 37(2), 193-216.

Van Dalen, H.P., Henkens, K. (2012). Intended and Unintended Consequences of a Publish-or-Perish Culture: A Worldwide Survey. Journal of the American Society for Information Science and Technology, 63(7), 1282-1293.

Waaijer, C. J., Macaluso, B., Sugimoto, C. R., Larivière, V. (2016). Stability and Longevity in the Publication Careers of US Doctorate Recipients. PloS one, 11(4), e0154741.

Watkinson, A., Nicholas, D., Thornley, C., Herman, E., Jamali, H. R., Volentine, R., ...and Tenopir, C. (2016). Changes in the Digital Scholarly Environment and Issues of Trust: An Exploratory, Qualitative Analysis. Information Processing E Management, 52(3), 446-458.

\title{
Attitudes and Behavior of Junior Researchers - Early Findings of an International Study with a Particular Focus on Polish Researchers
}

\begin{abstract}
Purpose/Thesis: The aim of this study is to identify the changes in scholarly communication based on the analysis of attitudes and behaviors of junior researchers.

Approach/Methods: The study is being conducted in seven countries over a three-year period from 2016 to 2018 using a deep interview method. During the first year of the study, 116 early-career researchers have participated, including 10 participants from the University of Warmia and Mazury in Olsztyn, Poland.

Results and conclusions: The majority of respondents from all countries have drawn attention to the fact that they were overwhelmed with their professional duties and unstable work environment. Their focus on publishing papers in highly-ranked journals was noticeable.

Originality/Value: It was first longitudinal and international study on changes in the scholarly communication among junior researchers.
\end{abstract}

\section{Keywords}

Early career researchers. International study. Scholarly communication. 
Dr hab. MARZENA ŚWIGOŃ, prof. UWM specjalizuje się w problematyce zarzadzania i dzielenia się informacja $i$ wiedza. Habilitowała się w zakresie bibliologii i informatologii na Uniwersytecie Wrocławskim w 2013 r. Pracuje w Instytucie Historii i Stosunków Międzynarodowych Uniwersytetu Warmińsko-Mazurskiego w Olsztynie, kieruje Pracowniq Badań nad Komunikacja i Zarzadzaniem Informacja. Najważniejsze publikacje: M. Świgoń (2013). Personal Knowledge and Information Management - Conception and Exemplification. Journal of Information Science, 39(6); M. Świgoń (2011). Library Anxiety Among Polish Students: Development and Validation of the Polish Library Anxiety Scale. Library \& Information Science Research, 33(2); M. Świgoń (2011). Information Limits - Definition, Types and Typologies. Aslib Proceedings: New Information Perspectives, 63(4).

Kontakt $z$ autorka: marzena.swigon@uwm.edu.pl Pracownia Badań nad Komunikacja i Zarzadzaniem Informacja Instytut Historii i Stosunków Międzynarodowych Wydziat Humanistyczny

Uniwersytet Warmińsko-Mazurski w Olsztynie ul. Kurta Obitza 1 10-725 Olsztyn

DAVID NICHOLAS (PhD. DSc. MPhil.) jest kierownikiem niezależnego centrum badawczego CIBER Research Ltd. i profesorem na University of Tennessee. Autor kilkuset publikacji z obszaru nauki o informacji, komunikacji naukowej i zachowań informacyjnych. Do najnowszych należa m.in.: D. Nicholas, E. Herman, D. Clark (2016). Scholarly Reputation Building - How Does ResearchGate Fare? International Journal of Knowledge Content Development E Technology,6(2); D. Nicholas, D. Clark, E. Herman (2016). ResearchGate: Reputation Uncovered. Learned Publishing, 29(3); D. Nicholas, H. R. Jamali, A. Watkinson, E. Herman, C. Tenopir, R. Volentine, S. Allard, K. Levine (2015). Do Younger Researchers Assess Trustworthiness Differently When Deciding What to Read and Cite and Where to Publish? International Journal of Knowledge Content Development \& Technology,5(2).

Kontakt $z$ autorem:

CIBER Research Ltd.

1 Westwood Farmhouse

Greenham

Newbury

RG14 7RU 